\title{
Preclinical Evaluation of Combined Topoisomerase and Proteasome Inhibition Against Pediatric Malignancies
}

\author{
EDVIN DESTANOVIC, JOACHIM BOOS and CLAUDIA LANVERS-KAMINSKY
}

Department of Pediatric Hematology and Oncology, University Children's Hospital, Muenster, Germany

\begin{abstract}
Background/Aim: The toxicity of the proteasome inhibitor MG132 was tested alone and combined either with the topoisomerase I inhibitor topotecan or the topoisomerase II inhibitor etoposide against a panel of 18 cell lines representing six pediatric tumor types. Materials and Methods: MG132, topotecan, etoposide and their combination were evaluated. Cell viability was determined by the 3-(4,5-dimethylthiazol-2-yl)-2,5-diphenyltetrazolium bromide assay. Combination indices for simultaneous treatment schedules were determined by the method of Chou and Talalay. Results: Concentrations inducing growth inhibition of 50\% $\left(\mathrm{GI}_{50} \mathrm{~s}\right)$ ranged between 0.140-1.30 $\mu \mathrm{mol} / \mathrm{l}$ (median=0.55 umol/I) for MG132. GI S0s $_{\text {s }}$ of 0.004-3.48 umol/l (median $=30 \mathrm{nmol} / \mathrm{I}$ ) were calculated for topotecan

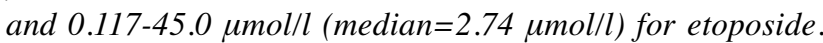
Additive/synergistic effects were observed in eight cell lines (including all Ewing sarcoma cell lines) for the combination of MG132 with etoposide, but only in three cell lines for its combination with topotecan. Conclusion: The combination of proteasome and topoisomerase II inhibitor deserves further evaluation, especially for Ewing sarcoma.
\end{abstract}

Cytotoxic chemotherapy is essential for the treatment of many cancer types. Childhood cancers in particular respond well to cytotoxic chemotherapy and about $60 \%$ of children with cancer can be cured by treatment regimens based on cytotoxic chemotherapy $(1,2)$. However, for tumors, that only poorly respond to established cytotoxic anticancer drugs, there is still an urgent need for new therapeutic options including new anticancer drugs $(3,4)$.

Correspondence to: Claudia Lanvers-Kaminsky, Ph.D., University Children's Hospital, Department of Pediatric Hematology and Oncology, Albert Schweitzer Campus. 1A1, D-48149 Muenster, Germany. Tel: +49 2518355693, Fax: +49 2518355740, e-mail: lanvers@uni-muenster.de

Key Words: Proteasome, MG132, topoisomerase, etoposide, topotecan, pediatric malignancies, Ewing sarcoma.
In recent years, high-throughput screening techniques have provided vast amounts of information on tumor characteristics and identified numerous novel targets for cancer treatment. From these, proteasome inhibition has emerged as an attractive anticancer target $(4,5)$.

Along with the endosome-lysosome pathway the ubiquitinproteasome pathway (UPP) constitutes one of the main routes of intracellular protein turnover. It is responsible for the degradation of unneeded, damaged or misfolded proteins by proteolysis and digests about $80-90 \%$ of intracellular proteins. Therefore, the UPP plays a crucial role in cellular homeostasis by affecting cell growth, differentiation, apoptosis, signal transduction, antigen processing and inflammatory responses (6). Moreover, the UPP interacts with the turnover of oncogenes and tumor-suppressor genes and proteasome inhibition was demonstrated to inhibit growth and to induce apoptosis of various tumor cells in vitro and in vivo (7-12).

Bortezomib (Velcade, PS-341) was the first proteasome inhibitor approved by the US Food and Drug Administration as a third-line therapy for relapsed and refractory multiple myeloma (MM) in 2003. It is approved as a frontline treatment for $\mathrm{MM}$ and five other proteasome inhibitors have also entered clinical trials (13-17).

Despite the impressive activity of proteasome inhibition against $\mathrm{MM}$, its activity as a single agent against solid tumors has been less promising (18-22).

Because preclinical and clinical studies indicated that proteasome inhibition can increase the toxicity of other anticancer drugs, herein we evaluated the effects of the proteasome inhibitor MG132 on the toxicity of the topoisomerase I inhibitor topotecan and the topoisomerase II inhibitor etoposide against a panel of 18 tumor cell lines, which represented six different pediatric tumor types (23-25).

\section{Materials and Methods}

Cell culture. The cytostatic and cytotoxic effects of MG132, topotecan and etoposide were tested on a panel of 18 human tumor cell lines. This panel comprised six pediatric tumor types and included Ewing sarcoma (EWS) cell lines CADO-ES-1, STA-ET-1, STA-ET-2.1 and VH-64; neuroblastoma (NB) cell lines IMR5, SMS-KCN, SHEP and 
SH-SY5Y; medulloblastoma (MB) cell lines DAOY and UW228.2; rhabdomyosarcoma (RMS) cell lines RD and RH30; osteosarcoma (OS) cell lines MNNG-HOS and OST; human T-acute lymphoblastic leukemia (ALL) cell lines CCRF-CEM and MOLT-4; human B-cell precursor ALL cell line REH; and the human acute myeloid leukemia cell line HL-60 (26). The cell lines were purchased as follows: CCRFCEM, MOLT-4, REH, HL-60, CADO-ES-1, SH-SY5Y, and RH-30 from the German Collection of Microorganisms and Cell Cultures (Braunschweig, Germany); DAOY, RD, MNNG-HOS, and IMR-5 from the American Tissue Culture Collection (LGC-Standards GmbH, Wesel, Germany). SMS-KCN, SHEP, and OST were kindly provided by Professor C. Poremba (Institute of Pathology, University of Duesseldorf, Germany). UW228.2 was provided by Professor Michael Frühwald (University Children's Hospital Muenster, Department of Pediatric Hematology and Oncology, Muenster, Germany) with kind permission of Professor John Silber (Department of Neurological Surgery, University of Washington, Washington, Seattle, USA). The EWS cell lines, STA-ET-1, STA-ET-2.1 and VH-64 were kindly provided by F. van Valen (University Hospital Muenster, Department of Orthopedics, Muenster, Germany). Cell lines were grown in RPMI 1640 medium supplemented with $2 \mathrm{mmol} / \mathrm{l} \mathrm{L}$-glutamine, $10 \%$ fetal bovine serum, $10^{5} \mathrm{U} / \mathrm{l}$ penicillin, $100 \mathrm{mg} / \mathrm{l}$ streptomycin, and $25 \mathrm{mg} / \mathrm{l}$ amphotericin B (GibcoBRL Cell Culture, Invitrogen $\mathrm{GmbH}$, Karlsruhe, Germany). Tissue culture flasks were incubated in a humidified atmosphere of $5 \% \mathrm{CO}_{2}$ at $37^{\circ} \mathrm{C}$. The EWS cell lines were grown on tissue culture flasks coated with collagen. Cell lines were regularly screened for mycoplasma infection and subjected to short tandem repeat analysis using the AmpFISTR Identifiler PCR Amplification kit (Applied Biosystems, Thermo Fisher Scientific, Lagenselbold, Germany) according to the manufacturer's instruction.

Cytotoxity assays. Cell viability was measured by the 3-(4,5dimethylthiazol-2-yl)-2,5-diphenyltetrazolium bromide (MTT) test, as described previously (26). Depending on doubling time 3,000 or 5,000 cells per well were seeded in 96-well plates and incubated for 72 hours before drug addition. MG132, etoposide, and topotecan were purchased from Tocris (Bio-Techne GmbH, Wiesbaden-Nordenstadt, Germany). MG132 and etoposide were dissolved in dimethyl sulfoxide (DMSO) and topotecan in sterile water. Stock solutions were further diluted with complete cell culture medium. Final test concentrations for single and combination treatments were $100 \mu \mathrm{mol} / 1,10 \mu \mathrm{mol} / 1,1$ $\mu \mathrm{mol} / 1,0.1 \mu \mathrm{mol} / 1,0.01 \mu \mathrm{mol} / 1,0.001 \mu \mathrm{mol} / 1$ and $0.0001 \mu \mathrm{mol} / 1$ for etoposide and $10 \mu \mathrm{mol} / 1,1 \mu \mathrm{mol} / 1,0.1 \mu \mathrm{mol} / 1,0.01 \mu \mathrm{mol} / 1,0.001$ $\mu \mathrm{mol} / 1,0.0001 \mu \mathrm{mol} / 1$, and $0.00001 \mu \mathrm{mol} / 1$ for MG132 and topotecan. Before drug addition, the cell viability of each cell line was analyzed by the MTT test (i.e. cell viability at $0 \mathrm{~h}$ ). The remaining plates were treated with $100 \mu$ of the respective drug dilutions resulting in a final volume of $200 \mu$ l. Control cells were treated with medium only. The cells were incubated for another 72 hours and thereafter analyzed for cell viability by the MTT test. MTT is reduced to violet formazan by vital and early apoptotic cells. The formation of blue formazan dye was quantified at a wavelength of $560 \mathrm{~nm}$ and a reference wavelength of $650 \mathrm{~nm}$ using an Elisa reader (Multiscan Ascent; Thermo Fisher Scientific, Langenselbold, Germany). In each experiment, each drug concentration was tested in quadruplicate and each experiment was repeated independently at least three times.

Calculation of cell viability. Drug concentrations which reduced cell viability by $50 \%$ compared to untreated controls and compared to cell viability at the start of the experiments were determined as previously described (26). In brief, means and standard deviations were calculated from quadruplicate optical density (OD) measurements determined in each experiment for each drug concentration. The means were compared to the mean ODs of untreated cells at the end of the experiment $(72 \mathrm{~h})$ : Equation 1: (mean OD of treated wells at $72 \mathrm{~h} /$ mean OD of untreated wells at $72 \mathrm{~h}) \times 100 \%$, and the mean OD of untreated cells at the start of the experiment $(0 \mathrm{~h}$ ): Equation 2: (mean OD of treated wells at 72 $\mathrm{h} /$ mean OD of untreated wells at $0 \mathrm{~h}) \times 100 \%$.

For the calculation of the drug concentration needed to reduce cell growth by $50 \%$ compared to untreated controls at the end of the incubation $(72 \mathrm{~h})\left(\mathrm{GI}_{50}\right)$ the rate of cell viability determined by Equation 1 was used. Using the highest test concentration $(\mathrm{C} 1)$ with a rate of cell viability (CV1) above $50 \%$ and the lowest test concentration $(\mathrm{C} 2)$ with a rate of cell viability below $50 \%(\mathrm{CV} 2)$ the $\mathrm{GI}_{50}$ was calculated as follows: $\mathrm{GI}_{50}=50 \% \times[(\mathrm{C} 1-\mathrm{C} 2) /(\mathrm{CV} 1-\mathrm{CV} 2)]$.

For the calculation of the drug concentration needed to kill $50 \%$ of the cells compared to the start of drug exposure $(0 \mathrm{~h})\left(\mathrm{LC}_{50}\right)$, the rate of cell viability determined by Equation 2 was used. Using the highest test concentration (C3) with a rate of cell viability (CV3) above $50 \%$ and the lowest test concentration (C4) with the rate of cell viability below $50 \%(\mathrm{CV} 4)$ the $\mathrm{LC}_{50}$ was calculated as follows: $\mathrm{LC}_{50}=50 \% \times[(\mathrm{C} 3-\mathrm{C} 4) /(\mathrm{CV} 3-\mathrm{CV} 4)]$.

Mean $\mathrm{GI}_{50}$ and $\mathrm{LC}_{50}$ were calculated for each cell line from independent experiments and the mean and median $\mathrm{GI}_{50}$ and $\mathrm{LC}_{50}$ of the whole cell line panel were calculated from the means of the individual cell lines. When a $\mathrm{GI}_{50}$ or $\mathrm{LC}_{50}$ was above the highest test concentration, the highest test concentration was used to calculate mean or median. Low $\mathrm{GI}_{50}$ and $\mathrm{LC}_{50}$ indicate drug sensitivity, whereas high $\mathrm{GI}_{50}$ and $\mathrm{LC}_{50}$ indicate drug resistance.

Additive, synergistic and antagonistic effects for drug combinations were calculated according to the method of Chou and Talalay $(27,28)$. Combination indices of less than 1 indicate synergistic, combination indices of 1 additive, and combination indices greater than one 1 antagonistic effects.

mRNA expression of ATP-binding cassette $(A B C)$ transporters. mRNA expression analysis of $A B C B 1, A B C C 1, A B C C 2, A B C C 3$, $A B C C 5, A B C C 6$, and $A B C G 2$ transporter genes was performed by quantitative real-time polymerase chain reaction (PCR) on an $\mathrm{ABI}$ Prism 7700 sequence detection system (Applied Biosystems, Thermo Fisher Scientific ) with commercially available 6-carboxyfluoresceinlabeled probes and primers purchased from Applied Biosystems (Hs01067802_m1 for $A B C B 1$; Hs00219905_m1 for $A B C C 1$, $\mathrm{Hs} 00166123 \_\mathrm{m} 1$ for $A B C C 2$, Hs00358656_m1 for $A B C C 3$, Hs00981089_m1 for $A B C C 5, \mathrm{Hs} 01081201 \_\mathrm{m} 1$ for $A B C C 6$, Hs01053790_m1 for $A B C G 2$ ) as previously described (26). For normalization of expression, the housekeeping gene glyceraldehyde 3-phosphate dehydrogenase $(G A P D H)$ was selected. Data were collected and analyzed with the Sequence Detector Software (SDS2.2; Applied Biosystems, Thermo Fisher Scientific). Analysis of the gene expression as relative quantity (RQ) data was performed using the $2^{-\Delta \Delta \mathrm{Ct}}$ method. Each cell line was analyzed in triplicate for target mRNA expression.

Statistical analysis. Statistical analysis was carried out using Sigma Plot 13.0 software (Systat Software GmbH, Erkrath, Germany). Correlation analyses were calculated by Pearson product moment or Spearman ranked correlation as indicated. Friedman repeatedmeasures analysis of variance on ranks was used for multiple 
Table I. Mean concentration reducing cell viability by $50 \%$ compared to untreated controls $\left(G_{50}\right)$ and concentration reducing cell viability by $50 \%$ compared to cell viability at the start of the experiment $\left(L C_{50}\right)$ for $M G 132$, etoposide and topotecan in 18 tumor cell lines. Means were calculated from three independent experiments.

\begin{tabular}{|c|c|c|c|c|c|c|c|}
\hline \multirow[t]{2}{*}{ Tumor type } & \multirow[b]{2}{*}{ Cell line } & \multicolumn{2}{|c|}{ MG132 } & \multicolumn{2}{|c|}{ Etoposide } & \multicolumn{2}{|c|}{ Topotecan } \\
\hline & & $\mathrm{GI}_{50}(\mu \mathrm{mol} / \mathrm{l})$ & $\mathrm{LC}_{50}(\mu \mathrm{mol} / \mathrm{l})$ & $\mathrm{GI}_{50}(\mu \mathrm{mol} / 1)$ & $\mathrm{LC}_{50}(\mu \mathrm{mol} / \mathrm{l})$ & $\mathrm{GI}_{50}(\mu \mathrm{mol} / 1)$ & $\mathrm{LC}_{50}(\mu \mathrm{mol} / \mathrm{l})$ \\
\hline \multirow[t]{4}{*}{ Ewing sarcoma } & CADO-ES-1 & 0.67 & 2.82 & 5.38 & 30.3 & 0.007 & 0.043 \\
\hline & STA-ET-1 & 0.58 & 1.35 & 0.60 & 15.8 & 0.008 & 0.592 \\
\hline & STA-ET- 2.1 & 0.60 & 2.59 & 3.24 & 48.4 & 0.041 & 2.18 \\
\hline & VH-64 & 0.50 & 0.82 & 1.93 & 42.6 & 0.019 & 6.46 \\
\hline \multirow[t]{4}{*}{ Leukemia } & CCRF-CEM & 0.24 & 0.59 & 2.24 & 37.4 & 0.023 & 0.079 \\
\hline & HL-60 & 1.30 & 2.35 & 0.28 & 37.8 & 0.005 & 0.009 \\
\hline & MOLT-4 & 0.46 & 0.95 & 0.12 & 19.0 & 0.004 & 0.033 \\
\hline & REH & 0.55 & 0.94 & 0.37 & 12.7 & 0.005 & 0.027 \\
\hline \multirow[t]{2}{*}{ Medulloblastoma } & DAOY & 0.46 & 3.37 & 3.36 & 49.2 & 0.070 & 4.35 \\
\hline & UW228.2 & 0.55 & 5.73 & 13.9 & $>100$ & 2.68 & 19.6 \\
\hline \multirow[t]{4}{*}{ Neuroblastoma } & IMR-5 & 0.55 & 1.06 & 2.09 & 37.9 & 0.009 & 0.059 \\
\hline & SMS-KCN & 0.38 & 0.82 & 6.32 & 83.7 & 0.264 & 1.98 \\
\hline & SHEP & 0.47 & 0.80 & 45.0 & 88.8 & 0.903 & 5.47 \\
\hline & SH-SY5Y & 0.65 & 3.28 & 4.76 & 64.1 & 0.031 & 7.22 \\
\hline \multirow[t]{2}{*}{ Osteosarcoma } & MNNG-HOS & 0.80 & 1.16 & 12.9 & 49.0 & 3.48 & 9.03 \\
\hline & OST & 0.69 & 4.45 & 4.68 & 35.2 & 0.662 & 15.6 \\
\hline \multirow[t]{2}{*}{ Rhabdomyosarcoma } & $\mathrm{RD}$ & 0.14 & 2.16 & 1.80 & 70.5 & 0.043 & 0.846 \\
\hline & RH-30 & 0.47 & 1.28 & 0.94 & 19.2 & 0.025 & 0.65 \\
\hline
\end{tabular}

comparisons of $\mathrm{GI}_{50}$ and $\mathrm{LC}_{50}$ of etoposide, topotecan, and $\mathrm{MG} 132$. Results were considered significant when $p<0.05$.

\section{Results}

MG132 showed substantial cytotoxicity against all cell lines tested. $\mathrm{GI}_{50}$ ranged from $140 \mathrm{nmol} / \mathrm{l}$ to $1.30 \mu \mathrm{mol} / \mathrm{l}$ (median $=0.55 \mu \mathrm{mol} / \mathrm{l}$, mean=0.56 $\mu \mathrm{mol} / \mathrm{l}$ ). For the reduction of cell viability below $50 \%$ compared to the start of the experiment $\left(\mathrm{LC}_{50}\right)$ mean MG132 concentrations of $2.03 \mu \mathrm{mol} / 1$ were needed $($ median $=1.32 \mu \mathrm{mol} / \mathrm{l}$; range $=590 \mathrm{nmol} / \mathrm{l}-5.73 \mu \mathrm{mol} / \mathrm{l})$. The RMS cell line RD and the leukemia cell line CCRF-CEM were the most sensitive cell lines. The leukemia cell line HL-60 displayed a resistant phenotype, with $\mathrm{GI}_{50}$ s distinctly above the overall mean $\mathrm{GI}_{50}$. The remaining cell lines were of intermediate sensitivity, with $\mathrm{GI}_{50} \mathrm{~s}$ scattered around the mean $\mathrm{GI}_{50}$ of $0.56 \mu \mathrm{mol} / 1$ (Table I).

The $\mathrm{GI}_{50} \mathrm{~s}$ determined for topotecan ranged between 4 $\mathrm{nmol} / 1$ and $3.48 \mu \mathrm{mol} / 1$ (median=30 nmol/, mean=0.46 $\mu \mathrm{mol} / \mathrm{l}) . \quad \mathrm{LC}_{50} \mathrm{~s}$ ranged from $9 \mathrm{nmol} / \mathrm{l}$ to $19.6 \mu \mathrm{mol} / \mathrm{l}$ (median=1.41 $\mu \mathrm{mol} / 1$, mean $=4.13 \mu \mathrm{mol} / \mathrm{l}$ ). With $\mathrm{GI}_{50}$ s below $10 \mathrm{nmol} / 1$, the EWS cell lines (CADO-ES-1, STA-ET-1), leukemia cell lines (HL-60, MOLT-4, REH) and the NB cell line IMR5 were the most sensitive. With $\mathrm{GI}_{50}$ s between 10 $\mathrm{nmol} / \mathrm{l}$ and $100 \mathrm{nmol} / \mathrm{l}$, the EWS cell lines STA-ET-2.1 and VH-64, RMS cell lines RD and RH-30, NB cell line SHSY5Y and the MB cell line DAOY showed intermediate sensitivity. With $\mathrm{GI}_{50} \mathrm{~S}$ above $100 \mathrm{nmol} / \mathrm{l}$, the $\mathrm{NB}$ cell lines SMS-KCN and SHEP, the MB cell line DAOY and the OS cell lines (OST and MNNG-HOS) displayed a resistant phenotype (Table I).

For etoposide, $\mathrm{GI}_{50} \mathrm{~s}$ were within the range of $117 \mathrm{nmol} / \mathrm{l}$ $45.0 \mu \mathrm{mol} / 1$ (median=2.74 $\mu \mathrm{mol} / 1$, mean=6.11 $\mu \mathrm{mol} / 1) . \mathrm{LC}_{50} \mathrm{~s}$ ranged from $12.7 \mu \mathrm{mol} / \mathrm{l}$ to more than $100 \mu \mathrm{mol} / \mathrm{l}$ (median=40.2 $\mu \mathrm{mol} / 1$, mean=46.8 $\mu \mathrm{mol} / \mathrm{l}$ ). With $\mathrm{GI}_{50} \mathrm{~s}$ below $1 \mu \mathrm{mol} / 1$, the EWS cell line STA-ET-1, leukemia cell lines (HL-60, MOLT-4 and REH), and the RMS cell line RH-30 displayed a sensitive phenotype. With $\mathrm{GI}_{50} \mathrm{~S}$ above $10 \mu \mathrm{mol} / 1$, the MB cell line UW228.2 and the OS cell line MNNG-HOS were the most resistant, while the remaining cell lines (CADO-ES-1, STA-ET-2.1, CCRF-CEM, DAOY, IMR5, SH-SY5Y, OST and RD) were of intermediate sensitivity, with $\mathrm{GI}_{50} \mathrm{~s}$ between 1 and $10 \mu \mathrm{mol} / 1$ (Table I). Figure 1 depicts the dose-response curves for MG132, etoposide, and topotecan of the four EWS cell lines.

With respect to their mean $\mathrm{GI}_{50} \mathrm{~S}$ and $\mathrm{LC}_{50} \mathrm{~s}$, the overall toxicities of MG132 and topotecan were comparable in this cell line panel. However, the differences between the most sensitive and most resistant cell lines were about three orders of magnitude for topotecan and only about one order of magnitude for MG132. Compared to MG132 and topotecan, etoposide was 10-20 times less cytotoxic $[p<0.001$, Friedman repeated-measures analysis of variance on ranks, all pairwise multiple comparison procedures 


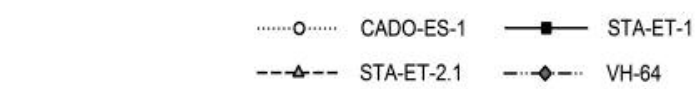

A

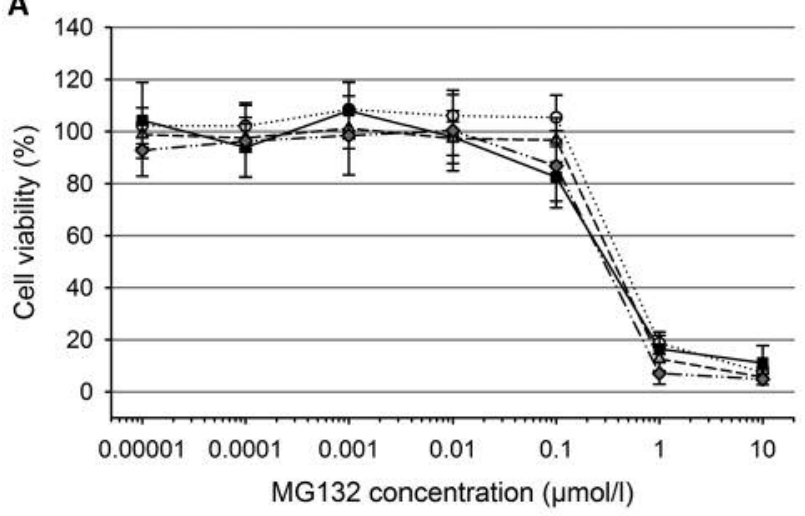

B

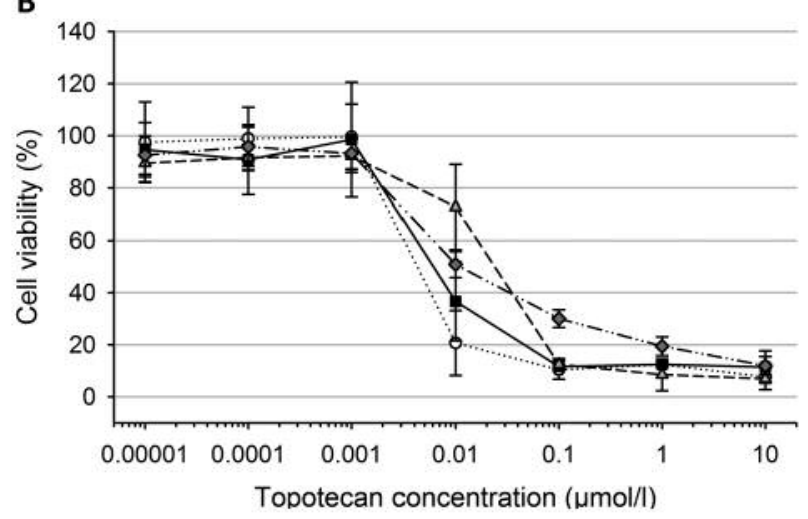

C

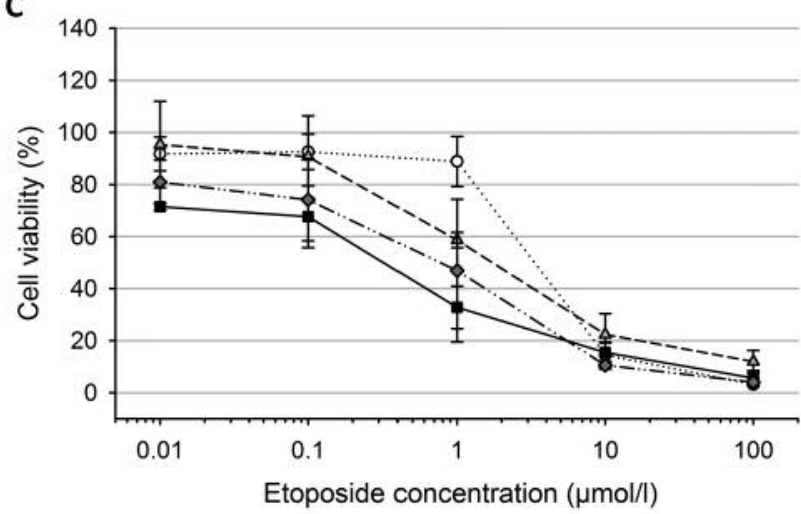

Figure 1. Cell viability of the Ewing sarcoma cell lines CADO-ES-1, STA-ET-1, STA-ET-2.1 and VH-64 after 72-h exposure to increasing concentrations of MG132 (A), topotecan (B) and etoposide (C). The dots represent means and the error bars represent standard deviations from three individual experiments.

(Tukey test)]. Although topotecan and MG132 did not differ with respect to their mean $\mathrm{GI}_{50} \mathrm{~s}$ and $\mathrm{LC}_{50} \mathrm{~s}$, no correlation was observed between $\mathrm{GI}_{50} \mathrm{~s}$ and $\mathrm{LC}_{50} \mathrm{~s}$ of MG132 and topotecan for individual cell lines (correlation coefficient for $\mathrm{GI}_{50} \mathrm{~s}=-0.05, p=0.837$, Spearman ranked correlation).

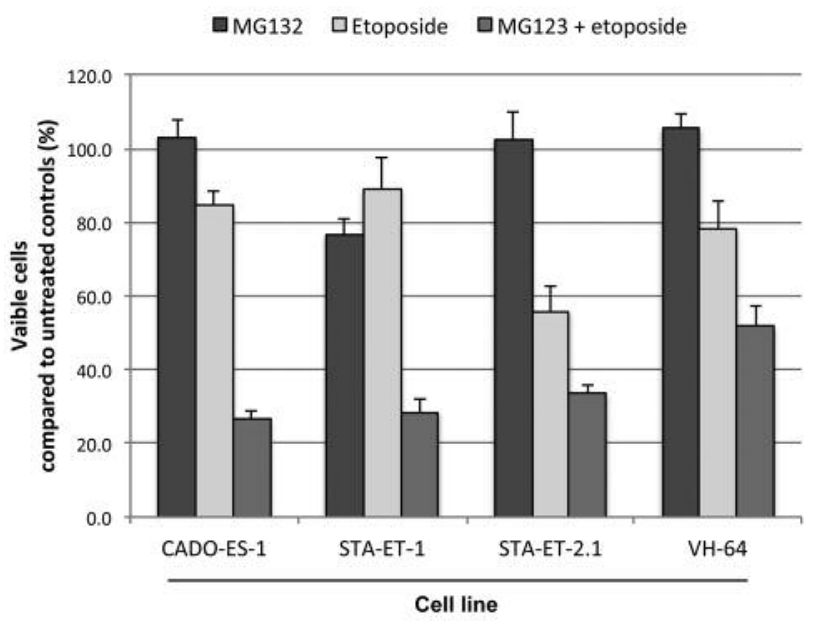

Figure 2. Cell viability of Ewing sarcoma cell lines CADO-ES-1, STAET-1, STAT-ET-2.1, and VH-64 exposed for $72 \mathrm{~h}$ to MG132 (0.1 umol/l), etoposide (1 $\mu \mathrm{mol} / \mathrm{l})$ and their combination $(0.1 \mu \mathrm{mol} / \mathrm{l}$ MG132 and 1 umol/l etoposide). The bars represent means and the error bars represent standard deviations from quadruplicate measurements of a representative experiment.

Similar observations were made for correlation analysis of $\mathrm{GI}_{50} \mathrm{~s}$ as well as $\mathrm{LC}_{50} \mathrm{~s}$ between MG132 and etoposide (correlation coefficient for $\mathrm{GI}_{50} \mathrm{~s}=0.112, p=0.650$, Spearman ranked correlation). However, for etoposide and topotecan, high correlations between $\mathrm{GI}_{50} \mathrm{~s}$ as well as $\mathrm{LC}_{50} \mathrm{~s}$ were observed, although not all cell lines which were sensitive to topotecan were sensitive to etoposide and vice versa (correlation coefficient for $\mathrm{GI}_{50} \mathrm{~s}=0.803, p<0.001$, Spearman ranked correlation) (Table I).

Significant correlations were observed for $A B C C l$ and $A B C C 3$ transporter expression and $\mathrm{GI}_{50} \mathrm{~s}$ determined for etoposide (ABCC1: $\mathrm{r}=0.734, p=0.001 ; A B C C 3: \mathrm{r}=0.735$, $p<0.001$; Pearson product moment correlation). $A B C C 1$, $A B C C 2$, and $A B C C 3$ mRNA expression significantly correlated with $\mathrm{GI}_{50} \mathrm{~s}$ for topotecan $(A B C C 1$ : $\mathrm{r}=0.622$, $p=0.006 ; A B C C 2: \mathrm{r}=0.520, p=0.027 ; A B C C 3: \mathrm{r}=0.729$, $p=0.001$; Pearson product moment correlation). But no correlation was found for $\mathrm{GI}_{50} \mathrm{~s}$ and $\mathrm{LC}_{50} \mathrm{~s}$ of MG132 and any of the $\mathrm{ABC}$ transporters analyzed.

For MG132 and etoposide combined in a fixed ratio of $1: 10$, synergistic effects were observed for two out of four EWS cell lines (CADO-ES-1 and STA-ET-1), two out of four leukemia cell lines (HL-60 and MOLT-4), and the NB cell line SHEP. In addition, additive effects were detectable for the EWS cell lines STA-ET-2.1 and VH-64, and the OS cell line MNNG-HOS. For both RMS and both MB cell lines as well as three out of four NB cell lines (IMR-5, SMSKCN, SH-SY5Y), only antagonistic effects were observed (Table II). If the combination of etoposide and MG132 were 
Table II. Combination indices (CI) calculated according to Chou and Talalay $(27,28)$. Means and standard deviation (SD) were calculated from three independent experiments.

\begin{tabular}{|c|c|c|c|}
\hline & & $\mathrm{CI}(\operatorname{mean} \pm \mathrm{SD})$ & $\mathrm{CI}(\operatorname{mean} \pm \mathrm{SD})$ \\
\hline Tumor type & Cell line & MG132+etoposide (ratio 1:10) & MG132+topotecan (ratio 1:1) \\
\hline \multirow[t]{4}{*}{ Ewing sarcoma } & CADO-ES-1 & $0.56 \pm 0.46$ & $2.12 \pm 1.61$ \\
\hline & STA-ET-1 & $0.55 \pm 0.54$ & $2.02 \pm 1.63$ \\
\hline & STA-ET-2.1 & $1.00 \pm 1.05$ & $1.46 \pm 0.58$ \\
\hline & VH-64 & $1.07 \pm 1.08$ & $3.57 \pm 3.32$ \\
\hline \multirow[t]{4}{*}{ Leukemia } & CCRF-CEM & $1.48 \pm 1.26$ & $3.17 \pm 2.74$ \\
\hline & HL-60 & $0.64 \pm 0.45$ & $1.04 \pm 0.13$ \\
\hline & MOLT-4 & $0.63 \pm 0.39$ & $1.54 \pm 0.71$ \\
\hline & REH & $1.27 \pm 0.67$ & $1.03 \pm 0.31$ \\
\hline \multirow[t]{2}{*}{ Medulloblastoma } & DAOY & $1.78 \pm 0.50$ & $1.19 \pm 0.40$ \\
\hline & UW228.2 & $1.83 \pm 0.45$ & $9.87 \pm 14.2$ \\
\hline \multirow[t]{4}{*}{ Neuroblastoma } & IMR-5 & $10.67 \pm 7.30$ & $1.72 \pm 0.89$ \\
\hline & SMS-KCN & $1.13 \pm 0.04$ & $1.16 \pm 0.04$ \\
\hline & SHEP & $0.74 \pm 0.16$ & $2.08 \pm 1.55$ \\
\hline & SH-SY5Y & $1.74 \pm 0.60$ & $1.56 \pm 0.61$ \\
\hline \multirow[t]{2}{*}{ Osteosarcoma } & MNNG-HOS & $1.08 \pm 0.25$ & $6.94 \pm 6.06$ \\
\hline & OST & $1.72 \pm 0.39$ & $6.58 \pm 4.82$ \\
\hline \multirow[t]{2}{*}{ Rhabdomyosarcoma } & $\mathrm{RD}$ & $1.11 \pm 0.25$ & $2.45 \pm 0.19$ \\
\hline & RH-30 & $1.14 \pm 0.08$ & $0.70 \pm 0.15$ \\
\hline
\end{tabular}

only synergistic $(\mathrm{CI}<1)$ on etoposide-resistant cells (high $\mathrm{GI}_{50}$ or $\mathrm{LC}_{50}$ ), a negative association would be expected between $\mathrm{GI}_{50}$ or $\mathrm{LC}_{50}$ for etoposide and the combination index for the combination of MG132 and etoposide. In contrast, synergy in etoposide-sensitive cell lines would have resulted in a positive association. However, beneficial effects of MG132 combined with etoposide were observed for etoposide-sensitive as well as etoposide-resistant cell lines. For the EWS cell lines, MG132 concentrations of 100 nmol/1, which had only little effect on cell viability, combined with $1 \mu \mathrm{mol} / 1$ etoposide, which also only slightly affected the viability of EWS cell lines, significantly reduced the viability of all four EWS cell lines by $50 \%$ and more (Figure 2).

Topotecan and MG132 were combined in a fixed ratio of $1: 1$. For this combination, synergistic effects were only observed for the RMS cell line RH-30, and additive effects were only detected for the leukemia cell lines HL-60 and REH. For all other cell lines, only antagonistic effects were observed with this drug combination. Correlation analysis between combination indices calculated according to Chou and Talalay and $\mathrm{GI}_{50} \mathrm{~s}$ for topotecan indicated that cell lines sensitive to topotecan tended to be more sensitive to the combination of MG132 and topotecan than did topotecanresistant cell lines (correlation coefficient for $\mathrm{GI}_{50} \mathrm{~s}$ of topotecan and combination indices for MG132 and topotecan $=0.756, p<0.0005$, Spearman ranked correlation) (Tables I and II).

\section{Discussion}

The proteasome inhibitor bortezomib is established in frontline treatment of MM (12). As single agents, proteasome inhibitors have proven less successful in the treatment of other tumor types. However, the combination of proteasome inhibitors with other anticancer drugs might expand their therapeutic benefit to other malignancies $(24,25)$. We used the publicly available proteasome inhibitor MG132, as proof of concept, to evaluate the potential of proteasome inhibition combined with the topoisomerase poisons etoposide and topotecan against a panel of cell lines representing six of the most common and aggressive pediatric tumor types.

Etoposide is well established in the treatment of numerous cancer types, including the six pediatric tumor types in this panel (29). It forms a complex with topoisomerase II and DNA, which inhibits DNA synthesis and induces breaks in double-stranded DNA. Topotecan inhibits topoisomerase I by intercalation in DNA. Topoisomerase I relieves torsional strains during DNA replication by inducing single-strand breaks (30). Compared to etoposide, topotecan is less frequently used in pediatric cancer although responses have been observed in cases with numerous recurrent or refractory solid tumors (31). Both topoisomerase inhibitors showed dose-dependent cytotoxicity here on all 18 cell lines. The concentrations required to induce $50 \%$ growth inhibition and to reduce cell viability by $50 \%$ were within the range of previously published in vitro studies (32-36). Compared to 
topotecan, more than 10-fold higher concentrations of etoposide were needed for the same growth-inhibitory effects.

The toxicity of MG132 was altogether comparable to that of topotecan on this cell line panel. The median $\mathrm{GI}_{50}$ for MG132 was $550 \mathrm{nM}$, which was higher than the median $\mathrm{IC}_{50}$ reported for bortezomib $(23 \mathrm{nM})$ on the cell line panel of the pediatric preclinical testing program and the average growth inhibition of $50 \%$ value reported for bortezomib across the entire NCI cell panel $(7 \mathrm{nM})(18,19)$. This might be explained by the fact that bortezomib inhibits the proteasome at lower concentrations than $\mathrm{MG} 132\left(\mathrm{IC}_{50}\right.$ bortezomib versus MG132: 0.6 versus $100 \mathrm{nM}$ ) (37).

Since the UPP is important for the catabolism of cellular proteins, the mechanisms of action through which proteasome inhibitors can affect the growth of tumor cells are numerous. The prevention of the proteosomal degradation of inhibitor of kappa $\mathrm{B}(\mathrm{IkB} \alpha)$ and consequently the inhibition of nuclear factor kappa B (NF-kB) signaling is mainly considered responsible for the efficacy of proteasome inhibitors against MM (38-40). Inhibition of NF- $\mathrm{KB}$ signaling has also been attributed to the cytotoxic effects of proteasome inhibitors against other tumor types, such as breast cancer or neuroblastoma (41-42). Additional influences on other pathways were detected, which finally contributed to apoptosis induction in $\mathrm{MM}$ as well as other tumors, such as stabilization of p53, p27, p21, various cyclins and cyclin-dependent kinases, or the stabilization of pro-apoptotic proteins such as B-cell lymphoma (BCL) 2-associated X protein and BCL homology interacting-domain death agonist $(40,43)$. Inhibition of the UPP was also shown to increase the accumulation of misfolded proteins, which in turn promoted endoplasmatic reticulum stress and activated the unfolded protein response pathway (4446). Whether one of these mechanisms or, more probably, a combination of various mechanisms finally lead to the induction of apoptosis mainly depends on the tumor-driving pathways activated in the respective tumors and, thus, will vary between different tumor types. Moreover, it is very likely to vary even among different cell lines of one tumor type.

This is supported by the observation that although stabilization of functional p53 was reported to contribute to the toxicity of proteasome inhibitors (47), the toxicity of MG132 did not differ between cell lines with mutated p53 compared to wild-type $p 53$ in our cell line panel. Mutations in $p 53$ were described for eight out of the 18 cell lines (namely STA-ET2.1, CCRF-CEM, HL-60, MOLT-4, REH, DAOY, MNNGHOS, RD). For UW228.2, the mutation status was unknown and no mutations in $p 53$ were reported for the remaining cell lines (26). This indicates that alternative pathways apart from p53 stabilization through proteasome inhibition contributed to the observed toxicity of MG132 (Table I).

The mechanisms listed above were also reported to increase the toxicity of other anticancer drugs when combined with proteasome inhibitors. Proteasome inhibition was shown to increase the cytotoxicity of doxorubicin against cervical cancer cell lines through up-regulation of p53 and targets of p53 (47). In breast cancer cell lines, proteasome inhibitors increased the sensitivity of doxorubicin through inhibition of NF-kB signaling (48). In osteosarcoma cell lines, bortezomib was shown to sensitize to doxorubicin via reactive oxygen species dependent activation of endoplasmatic reticulum stress (44). Another study showed that down-regulation of NF-kB, of Bcell lymphoma-xL (BCL-xL) and PI3K/AKT increased the sensitivity of osteosarcoma cell lines to cisplatin (49). For multiple myeloma sequential as well as simultaneous exposure to bortezomib and etoposide increased the toxicity of etoposide by inhibition of etoposide-induced NF-kB activation and BCL2 up-regulation (50). For squamous cell carcinoma cell lines, similar observations were made, indicating that this combination might also work in other tumor types $(40,51)$. Ogiso et al. reported that proteasome inhibition reduced the degradation of topoiomerase II in colon cancer HT-29 and ovarian cancer A2780 cells and thus increased the sensitivity of these cell lines to topoisomerase II inhibitors such as etoposide (52). Regarding the multitude of pathways affected by proteasome inhibition and the number of pathways involved in apoptosis induction and tumor resistance, it is very probable that depending tumor type, various pathways induced by proteasome inhibition and anticancer drug exposure act in parallel and that, for example, defective p53 signaling might be masked by the effects on other pathways, such as NF-kB inhibition.

In view of the multiple mechanisms identified for additive or synergistic effects between proteasome inhibitors and anticancer drugs, it was somewhat surprising, that we only observed such effects in eight out of the 18 of cell lines (additive effects for three and synergistic effects for five cell lines) for the combination of MG132 with etoposide and only in three out of 18 cell lines (one synergistic and two additive effects) for the combination of MG132 with topotecan. This might have been related to the chosen mode of drug combination (co-exposure of drugs at a fixed ratio). Alternative schemes such as sequential use of proteasome inhibitor and topoisomerase inhibitor and different concentration ratios between proteasome and topoisomerase inhibitor might have yielded different results.

Although we did not further investigate the underlying mechanisms, our observations confirm the beneficial effects of proteasome and topoisomerase II inhibition for eight out of the 18 cell lines tested. The EWS cell lines of this panel merit particular attention, with synergistic/additive effects observed for all four EWS cell lines tested. Recently, Shukla et al. preclinically screened a library of 309,989 chemical compounds for growth inhibition of EWS and identified a class of benzyl4-piperidone compounds, which inhibited the 19S proteasome, as selectively inhibiting the growth of EWS cell lines. Further pre-clinical evaluation confirmed the efficacy of these 
compounds in vitro and in vivo. The fact that, these inhibitors did not eliminate tumor cells in vivo, argues for the combination of proteasome inhibitors with other anticancer drugs (53). In this respect, our observations indicate that the combination of proteasome inhibition and topoisomerase II inhibitors deserves further preclinical exploration for the treatment of pediatric malignancies, especially Ewing sarcoma.

\section{Acknowledgements}

This work fulfills the requirements for the medical doctoral thesis of E.D. The Authors thank Mrs Sandra Schulz for excellent technical assistance. This work was supported by the Federal Department of Research and Technology (01EC9801) and by "Horizont" Kinderkrebshilfe Weseke e.V.

\section{References}

1 Rossig C, Juergens H, Schrappe M, Moericke A, Henze G, Stackelberg A von, Reinhardt D, Burkhardt B, Woessmann W, Zimmermann M, Gadner H, Mann G, Schellong G, MauzKoerholz C, Dirksen U, Bielack S, Berthold F, Graf N, Rutkowski S, Calaminus G, Kaatsch P and Creutzig U: Effective childhood cancer treatment: the impact of large scale clinical trials in Germany and Austria. Pediatr Blood Cancer 60: 1574-1581, 2013.

2 Smith MA, Seibel NL, Altekruse SF, Ries LAG, Melbert DL, O'Leary M, Smith FO and Reaman GH: Outcomes for children and adolescents with cancer: challenges for the twenty-first century. J Clin Oncol 28: 2625-2634, 2010.

3 Norris RE and Adamson PC: Challenges and opportunities in childhood cancer drug development. Nature Rev Cancer 12: 776-782, 2012.

4 Lee A-H, Iwakoshi NN, Anderson KC and Glimcher LH: Proteasome inhibitors disrupt the unfolded protein response in myeloma cells. Proc Natl Acad Sci USA 100: 9946-9951, 2003.

5 King RW, Deshaies RJ, Peters JM and Kirschner MW: How proteolysis drives the cell cycle. Science 274: 1652-1659, 1996.

6 Ciechanover A: Proteolysis: from the lysosome to ubiquitin and the proteasome. Nat Rev Mol Cell Biol 6: 79-87, 2005.

7 Driscoll JJ and Dechowdhury R: Therapeutically targeting the SUMOylation, Ubiquitination and Proteasome pathways as a novel anticancer strategy. Target Oncol 5: 281-289, 2010.

8 Nalepa G, Rolfe M and Harper JW: Drug discovery in the ubiquitin-proteasome system. Nat Rev Drug Discov 5: 596-613, 2006.

9 Sterz J, Metzler I von, Hahne J-C, Lamottke B, Rademacher J, Heider U, Terpos E and Sezer O: The potential of proteasome inhibitors in cancer therapy. Expert Opin Inv Drug 17: 879-895, 2008.

10 Orlowski RZ and Kuhn DJ: Proteasome inhibitors in cancer therapy: lessons from the first decade. Clin Cancer Res 14: 1649-1657, 2008

11 Adams J: The proteasome: a suitable antineoplastic target. Nat Rev Cancer 4: 349-360, 2004

12 Molineaux SM: Molecular pathways: targeting proteasomal protein degradation in cancer. Clin Cancer Res 18: 15-20, 2012.

13 Kubiczkova L, Pour L, Sedlarikova L, Hajek R and Sevcikova S: Proteasome inhibitors-molecular basis and current perspectives in multiple myeloma. J Cell Mol Med 18: 947-961, 2014.
14 Orlowski RZ, Stinchcombe TE, Mitchell BS, Shea TC, Baldwin AS, Stahl S, Adams J, Esseltine D-L, Elliott PJ, Pien CS, Guerciolini R, Anderson JK, Depcik-Smith ND, Bhagat R, Lehman MJ, Novick SC, O'Connor OA and Soignet SL: Phase I trial of the proteasome inhibitor PS-341 in patients with refractory hematologic malignancies. J Clin Oncol 20: 4420-4427, 2002.

15 Jagannath S, Barlogie B, Berenson J, Siegel D, Irwin D, Richardson PG, Niesvizky R, Alexanian R, Limentani SA, Alsina M, Adams J, Kauffman M, Esseltine D-L, Schenkein DP and Anderson KC: A phase 2 study of two doses of bortezomib in relapsed or refractory myeloma. Br J Haematol 127: 165-172, 2004.

16 Richardson PG, Barlogie B, Berenson J, Singhal S, Jagannath S, Irwin D, Rajkumar SV, Srkalovic G, Alsina M, Alexanian R, Siegel D, Orlowski RZ, Kuter D, Limentani SA, Lee S, Hideshima T, Esseltine D-L, Kauffman M, Adams J, Schenkein DP and Anderson KC: A phase 2 study of bortezomib in relapsed, refractory myeloma. N Engl J Med 348: 2609-2617, 2003.

17 Infante JR, Mendelson DS, Burris HA, Bendell JC, Tolcher AW, Gordon MS, Gillenwater HH, Arastu-Kapur S, Wong HL and Papadopoulos KP: A first-in-human dose-escalation study of the oral proteasome inhibitor oprozomib in patients with advanced solid tumors. Invest New Drugs 34: 216-224, 2016.

18 Houghton PJ, Morton CL, Kolb EA, Lock R, Carol H, Reynolds CP, Keshelava N, Maris JM, Keir ST, Wu J and Smith MA: Initial testing (stage 1) of the proteasome inhibitor bortezomib by the pediatric preclinical testing program. Pediatr Blood Cancer 50: 37-45, 2008.

19 Adams J, Palombella VJ, Sausville EA, Johnson J, Destree A, Lazarus DD, Maas J, Pien CS, Prakash S and Elliott PJ: Proteasome inhibitors: a novel class of potent and effective antitumor agents. Cancer Res 59: 2615-2622, 1999.

20 Papandreou CN, Daliani DD, Nix D, Yang H, Madden T, Wang X, Pien CS, Millikan RE, Tu S-M, Pagliaro L, Kim J, Adams J, Elliott P, Esseltine D, Petrusich A, Dieringer P, Perez C and Logothetis CJ: Phase I trial of the proteasome inhibitor bortezomib in patients with advanced solid tumors with observations in androgen-independent prostate cancer. J Clin Oncol 22: 2108-2121, 2004.

21 Lenz HJ: Clinical update: Proteasome inhibitors in solid tumors. Cancer Treat Rev 29(Suppl 1): 41-48, 2003.

22 Cusack JC: Rationale for the treatment of solid tumors with the proteasome inhibitor bortezomib. Cancer Treat Rev 29(Suppl 1): 21-31, 2003.

23 Milano A, Iaffaioli RV and Caponigro F: The proteasome: a worthwhile target for the treatment of solid tumours? Eur J Cancer 43: 1125-1133, 2007.

24 Oakervee HE, Popat R, Curry N, Smith P, Morris C, Drake M, Agrawal S, Stec J, Schenkein D, Esseltine D-L and Cavenagh JD: PAD combination therapy (PS-341/bortezomib, doxorubicin and dexamethasone) for previously untreated patients with multiple myeloma. Br J Haematol 129: 755-762, 2005.

25 San Miguel JF, Schlag R, Khuageva NK, Dimopoulos MA, Shpilberg O, Kropff M, Spicka I, Petrucci MT, Palumbo A, Samoilova OS, Dmoszynska A, Abdulkadyrov KM, Delforge M, Jiang B, Mateos M-V, Anderson KC, Esseltine D-L, Liu K, Deraedt W, Cakana A, van de Velde H and Richardson PG: Persistent overall survival benefit and no increased risk of second malignancies with bortezomib-melphalan-prednisone versus melphalan-prednisone in patients with previously untreated multiple myeloma. J Clin Oncol 31: 448-455, 2013. 
26 Spaniol K, Boos $\mathrm{J}$ and Lanvers-Kaminsky C: An in vitro evaluation of the polo-like kinase inhibitor GW843682X against paediatric malignancies. Anticancer Drugs 22: 531-542, 2011.

27 Chou TC and Talalay P: Quantitative analysis of dose-effect relationships: the combined effects of multiple drugs or enzyme inhibitors. Adv Enzyme Regul 22: 27-55, 1984.

28 Chou T-C: Drug combination studies and their synergy quantification using the Chou-Talalay method. Cancer Res 70: 440-446, 2010.

29 Hande KR: Etoposide: four decades of development of a topoisomerase II inhibitor. Eur J Cancer 34: 1514-1521, 1998.

30 Staker BL, Feese MD, Cushman M, Pommier Y, Zembower D, Stewart L and Burgin AB: Structures of three classes of anticancer agents bound to the human topoisomerase I-DNA covalent complex. J Med Chem 48: 2336-2345, 2005.

31 Mascarenhas L, Felgenhauer JL, Bond MC, Villaluna D, Femino JD, Laack NN, Ranganathan S, Meyer J, Womer RB, Gorlick R, Krailo MD and Marina N: Pilot study of adding vincristine, topotecan, and cyclophosphamide to interval-compressed chemotherapy in newly diagnosed patients with localized Ewing sarcoma: A report from the Children's Oncology Group. Pediatr Blood Cancer 63: 493-498, 2016.

32 Wolf SJ, Wakelin LPG, He Z, Stewart BW and Catchpoole DR: In vitro assessment of novel transcription inhibitors and topoisomerase poisons in rhabdomyosarcoma cell lines. Cancer Chemother Pharmacol 64: 1059-1069, 2009.

33 Heinicke U and Fulda S: Chemosensitization of rhabdomyosarcoma cells by the histone deacetylase inhibitor SAHA. Cancer Lett 351: 50-58, 2014.

34 Lanvers-Kaminsky C, Nolting D-M, Köster J, Schröder A, Sandkötter $\mathrm{J}$ and Boos $\mathrm{J}$ : In vitro toxicity of Ukrain against human Ewing tumor cell lines. Anticancer Drugs 17: 1025-1030, 2006.

35 May WA, Grigoryan RS, Keshelava N, Cabral DJ, Christensen LL, Jenabi J, Ji L, Triche TJ, Lawlor ER and Reynolds CP: Characterization and drug resistance patterns of Ewing's sarcoma family tumor cell lines. PloS One 8: e80060, 2013.

36 Carol H, Houghton PJ, Morton CL, Kolb EA, Gorlick R, Reynolds CP, Kang MH, Maris JM, Keir ST, Watkins A, Smith MA and Lock RB: Initial testing of topotecan by the pediatric preclinical testing program. Pediatr Blood Cancer 54: 707-715, 2010.

37 Tsubuki S, Saito Y, Tomioka M, Ito H and Kawashima S: Differential inhibition of calpain and proteasome activities by peptidyl aldehydes of di-leucine and tri-leucine. J Biochem 119: 572-576, 1996.

$38 \mathrm{Ni} \mathrm{H}$, Ergin M, Huang Q, Qin JZ, Amin HM, Martinez RL, Saeed S, Barton K and Alkan S: Analysis of expression of nuclear factor kappa B (NF-kappa B) in multiple myeloma: down-regulation of NF-kappa B induces apoptosis. $\mathrm{Br} \mathrm{J}$ Haematol 115: 279-286, 2001.

39 Hideshima T, Chauhan D, Richardson P, Mitsiades C, Mitsiades N, Hayashi T, Munshi N, Dang L, Castro A, Palombella V, Adams J and Anderson KC: NF-kappa B as a therapeutic target in multiple myeloma. J Biol Chem 277: 16639-16647, 2002.

40 Mitsiades N, Mitsiades CS, Richardson PG, Poulaki V, Tai Y-T, Chauhan D, Fanourakis G, Gu X, Bailey C, Joseph M, Libermann TA, Schlossman R, Munshi NC, Hideshima T and Anderson KC: The proteasome inhibitor PS-341 potentiates sensitivity of multiple myeloma cells to conventional chemotherapeutic agents: therapeutic applications. Blood 101: 2377-2380, 2003.
41 Shi Y, Yu Y, Wang Z, Wang H, Bieerkehazhi S, Zhao Y, Suzuk L and Zhang H: Second-generation proteasome inhibitor carfilzomib enhances doxorubicin-induced cytotoxicity and apoptosis in breast cancer cells. Oncotarget 7: 73697-73710, 2016.

42 Guan S, Zhao Y, Lu J, Yu Y, Sun W, Mao X, Chen Z, Xu X, Pan $\mathrm{J}$, Sun $\mathrm{S}$ and Yang J: Second-generation proteasome inhibitor carfilzomib sensitizes neuroblastoma cells to doxorubicininduced apoptosis. Oncotarget 7: 75914-75925, 2016.

43 Zavrski I, Kleeberg L, Kaiser M, Fleissner C, Heider U, Sterz J, Jakob C and Sezer O: Proteasome as an emerging therapeutic target in cancer. Curr Pharm Des 13: 471-485, 2007.

44 Xian M, Cao H, Cao J, Shao X, Zhu D, Zhang N, Huang P, Li W, Yang B, Ying M and He Q: Bortezomib sensitizes human osteosarcoma cells to adriamycin-induced apoptosis through ROS-dependent activation of p-eIF $2 \alpha / \mathrm{ATF} 4 / \mathrm{CHOP}$ axis. Int $\mathbf{J}$ Cancer 141: 1029-1041, 2017.

45 Park HS, Jun do Y, Han CR, Woo HJ and Kim YH: Proteasome inhibitor MG132-induced apoptosis via ER stress-mediated apoptotic pathway and its potentiation by protein tyrosine kinase p561ck in human Jurkat T cells. Biochem Pharmacol 82: 1110$1125,2011$.

46 Obeng EA, Carlson LM, Gutman DM, Harrington WJ, Lee KP and Boise LH: Proteasome inhibitors induce a terminal unfolded protein response in multiple myeloma cells. Blood 107: 4907-4916, 2006.

47 Guo KY, Han L, Li X, Yang AV, Lu J, Guan S, Li H, Yu Y, Zhao $\mathrm{Y}$, Yang $\mathrm{J}$ and Zhang H: Novel proteasome inhibitor delanzomib sensitizes cervical cancer cells to doxorubicin-induced apoptosis via stabilizing tumor suppressor proteins in the p53 pathway. Oncotarget 8: 114123-114135, 2017.

48 Wang H, Yu Y, Jiang Z, Cao W-M, Wang Z, Dou J, Zhao Y, Cui $\mathrm{Y}$ and Zhang $\mathrm{H}$ : Next-generation proteasome inhibitor MLN9708 sensitizes breast cancer cells to doxorubicin-induced apoptosis. Sci Rep 6: 26456, 2016.

49 Sun F, Zhang Y, Xu L, Li S, Chen X, Zhang L, Wu Y and Li J: Proteasome inhibitor MG132 enhances cisplatin-induced apoptosis in osteosarcoma cells and inhibits tumor growth. Oncol Res, 2017. doi: 10.3727/096504017X15119525209765

50 Metzler I von, Heider U, Mieth M, Lamottke B, Kaiser M, Jakob $\mathrm{C}$ and Sezer O: Synergistic interaction of proteasome and topoisomerase II inhibition in multiple myeloma. Exp Cell Res 315: 2471-2478, 2009.

51 Sunwoo JB, Chen Z, Dong G, Yeh N, Crowl Bancroft C, Sausville E, Adams J, Elliott $\mathrm{P}$ and van Waes C: Novel proteasome inhibitor PS-341 inhibits activation of nuclear factorkappa B, cell survival, tumor growth, and angiogenesis in squamous cell carcinoma. Clin Cancer Res 7: 1419-1428, 2001.

52 Ogiso Y, Tomida A, Lei S, Omura S and Tsuruo T: Proteasome inhibition circumvents solid tumor resistance to topoisomerase II-directed drugs. Cancer Res 60: 2429-2434, 2000.

53 Shukla N, Somwar R, Smith RS, Ambati S, Munoz S, Merchant M, D'Arcy P, Wang X, Kobos R, Antczak C, Bhinder B, Shum D, Radu C, Yang G, Taylor BS, Ng CKY, Weigelt B, Khodos I, Stanchina E de, Reis-Filho JS, Ouerfelli O, Linder S, Djaballah $\mathrm{H}$ and Ladanyi M: Proteasome addiction defined in Ewing sarcoma is effectively targeted by a novel class of $19 \mathrm{~S}$ proteasome inhibitors. Cancer Res 76: 4525-4534, 2016.

Received May 4, 2018

Revised May 28, 2018 Accepted May 30, 2018 